\title{
An empirical study of student perception towards pedagogy, teaching style and effectiveness of online classes
}

\author{
Sona Vikas $^{1}$ (D) . Ashish Mathur ${ }^{2}$
}

Received: 29 January 2021 / Accepted: 20 October 2021 / Published online: 26 October 2021

(C) The Author(s), under exclusive licence to Springer Science+Business Media, LLC, part of Springer Nature 2021

\begin{abstract}
Purpose of the Research With online education taking centerstage in recent times, the primary objective of this study is to find out the student perception of online classes from teachers who had no past experience of online teaching, with respect to their teaching effectiveness, teaching style and pedagogy in an online classroom. This study is exploratory in nature. Using a structured questionnaire, 356 completed responses were received and analysed using the available research tools.

Principle Results The dynamics of education have changed overnight. The findings of the study indicate that pedagogy, teaching style and teaching effectiveness significantly affect student perception towards online classes by first time online teachers.

Major Conclusions The role of the teachers has changed drastically and there is a need for them to prepare themselves for the new normal using the suitable pedagogical tools for creating an effective online classroom.
\end{abstract}

Keywords Online Classes · Online Pedagogy · Teaching Effectiveness · Teaching Style $\cdot$ First time online teachers

Sona Vikas

sonavikas9@gmail.com

Ashish Mathur

ashishmth@gmail.com

1 IILM University, 1 Knowledge Centre, Golf Course Road, Gurugram 122003, India

2 Department of Business Administration, Faculty of Commerce and Management Studies, Jai Narain Vyas University, Jaswant Campus, Near Mohanpura Overbridge, Jodhpur 342001,

Rajasthan, India 


\section{Introduction}

Increased educational opportunities, new learning models and technological advances have fast influenced not only education but the society as a whole (Harasim, 2000). The online world has provided a space for educators to share knowledge, provide consultation and advice (Woollard, 2011). Pedagogical strategies have changed substantially (Dwivedi et al., 2019) and online learning has gained momentum with increased usage of ICT (Information and Communication Technologies). The domains of learning and teaching in higher education have experienced dramatic changes due to Covid-19 with a mandatory online education environment. Educational institutions (schools, colleges, and universities) have been quick to rapidly adapt technology and implement the practices of online education. Overnight, all teaching-learning went online irrespective of teachers having any past online teaching / learning experience. Before Covid-19, only selected educational institutions were providing internet-based online courses to complement their classroombased courses and, some educational institutions were providing distance education, but now almost all of the educational institutions have moved their teaching online or in virtual space as a new normal. The mediums, formats and technologies in teaching have changed, and the teaching style, pedagogy and effectiveness have all been drastically affected.

Online education is not a new area of research and different aspects of virtual learning have been deliberated in the past. Parker and Martin (2010) in their study discussed how the online class created an ecosystem facilitating learners and educators to interact collectively through various modes as if in conventional teaching environments. The online or virtual class environments are considered identical to conventional classroom as they both permit prompt reaction, encourage unanimity, and even decision-making in class tasks with real time resolution and explanation. This allows for supervised pacing and regulation of the learning procedure and assisting the evolution of class coherence (Schullo et al., 2007). Due to open access, online learning is able to provide greater opportunities for the learners. Ample learner-centred education opportunities are available in online teaching ecosystem satisfying learner's desire for conventional learning without physical presence in classroom. The online teaching ecosystem also entails reduced reliance on conventional 'one size fits all' form of direction. (Subramaniam \& Kandasamy, 2011).

Webster and Hackley (1997) in their study pointed that the performance of the learners is judged by marks obtained and it serves as performance measure for the teachers. They also recommended that the elements that apprehend the notions of effectiveness in the online class include learners' association \& involvement, technology self-efficacy, anticipated benefits from the technology engaged, corresponding benefit or disadvantage of online delivery \& cognitive engagement of the participants (students). Several surveys have proved that there exists meagre or no distinction among the performance of the learners in comparison to the academic broadcasting \& personal interactive teaching as researched by Wetzel et al. (1994) or amongst recorded lecture-based teaching \& personal interactive teaching as per Storck and Sproull (1995). According to another research study that was conducted 
by Leidner and Jarvenpaa (1993) and another by Dillon and Gunawardena (1995), there are 3 primary components which affect performance of online delivery which include (a) technology, (b) the traits of the instructor \& (c) the student's traits.

Hartley and Bendixen (2001) in their study stated that virtual or online learning environment being student centric needs more active participation from the learner. Students have to take ownership of his/her learning, become better time managers (Hill, 2002; Roper, 2007), learn to keep up with the pace of the class, and for wrapping-up the task on time (Discenza et al., 2002), \& be engaged participants to the instructions in the class (Garrison et al., 2004).

At the same time, there have been several studies related to the difficulties related to the digitally connected teaching and learning, availability of technologies to assist online teaching environment, availability of trained instructors to support digitally connected teaching and learning and requirements of students in digitally connected studying space has created challenges for the educational institutions. This turbulence ripples as the educational institutions are exploring and experimenting with several digitally connected teaching and learning technologies with new ones popping up every week. Adding to this bottleneck, the disinterested, fatigued and tired learners are opting out of online classes desiring for a fruitful digitally connected teaching and learning experience. These teething troubles linked to pedagogy, technological issues, learners' needs, etc. have created a gust in the digitally connected teaching and learning ecosystem. Apparently, it is not surprising that there are mixed views from all stakeholders about benefits of digitally connected teaching and learning.

This paper is an attempt to study the perception of school and university students towards the online classroom. Teachers who had no past experience of online teaching with respect to teaching effectiveness, teaching style and pedagogy during the Covid-19 took up the challenge of an unexpected and urgent need to teach virtually those subjects which were taught conventionally by them in past. (Rapanta et al., 2020). Coming from all backgrounds and ages with no experience with online teaching, these educators have had to work from home - prepare lessons as per the online requirements and teach from home environment alongside the pragmatic and technological problems that occurred. (Hodges et al., 2020).

Appropriately, it also raises a question, as to how students and teachers have been able to adapt to this new normal of digitally connected teaching and learning. Is this new methodology well accepted and adopted by teachers and students? Will this be the new norm for all future teaching-learning, eliminating the need for physical campus and personal interactive teachings? An effort is made to answer these questions through this study. To better understand the effectiveness of online learning, learners' perception, learners' attitudes, behaviours, and readiness need to be understood. This would help teachers in better designing online courses, methodologies, pedagogy, student engagement and finally resulting in fruitful learning experiences for the learners.

The current study is presented into several sections. The first section presents a brief overview of the online classroom and the concept of online learning to underline its significance as an important research domain. The next section 
reviews the available theory on online or virtual education and research questions arising out of the gaps in past studies. The consequent section presents the methods adopted for the current study and states our research objectives. Further on, the subsequent section deals with the results derived out of the responses received, analysed and discussed. The paper ends with the concluding remarks and propositions.

\section{Theory}

A systematic search method was followed by exploring various online databases for laying the proper research foundation and developing relevant research questions. The plan of exploring these credible published sources ensured that a proper foundation was laid for the study and it moved in the right direction to achieve the research objectives. To explore the most notable studies in this area, we used keywords such as history of online education, online teaching, online teacher roles, online teaching effectiveness, online teaching pedagogy, student satisfaction, learning outcome, virtual learning environment etc., and the Review is divided into different sections as given below.

\subsection{Online learning}

Agrawal et al (2016) conducted a research on assessing the factors affecting e-learning by studying the student perception in various universities towards e-learning usage and found that the instructor perspective, service quality and system quality were among the key factors that emerged to influence e-learning. Loh, et al (2016) examined the students' perception towards e-learning. The study was conducted to try and determine the effectiveness of the application of the different technologies in the various courses and teaching programs in a rapidly changing competitive educational environment. Another study on higher education by Efiloğlu \& Tingöy (2017) appraised the acceptance by students and usage of the virtual learning environments. Bower (2017) presented recommendations for learning design and implementation for online education in higher education and schools whereby the focus was on the impact of teaching pedagogy on learner effectiveness by creating an effective virtual world. Visvizi et al (2019) focused on the various approaches and styles of teaching and learning which integrate the emerging technologies to enhance the quality of higher education and innovative teaching pedagogy.

Samsudeen and Mohamed (2019) investigated those factors that could be influencing the use behaviour and the intention of e-learning by higher education students in the different state universities in Sri Lanka. The results indicated low adoption and implementation of the e-learning systems in the country and it was thus essential to enhance the learning experience of the students for improvement in their knowledge. Ugnich et al. (2019) in their study identified opportunities, special facets, and constraints of e-learning in the realms of higher inclusive education 
which needed to be tackled to enhance its effectiveness at the level of individual universities. Sarker et al (2019) in a study on the higher educational institutions in Gunesekera et al (2019) in their study reviewed e-learning user relationships and provided valuable insights towards the teaching pedagogy. The factors considered for this study included interactions of the student and instructor, student and student, and student and content. Student engagement in an online class was increased by the speedy response of the instructor to the online activities as well as queries of the students (Dwivedi et al., 2019).

Federman (2019) developed a framework for understanding the various interruptions in online training and their effects on learning. Chopra et al (2019) shared their results for a study on the effectiveness of e-learning from the perspectives of the students, indicating that it is the system quality as well as the service quality which add to the e-learning system as equated to the quality of information. In case of online education, student satisfaction is considered as an indicator of the quality of the education system and this was highlighted in the study by Rodríguez and Fahara (2010).

\subsection{Factors affecting online learning}

\subsubsection{Teaching effectiveness}

The effectiveness of teaching has been explored comprehensively in for several decades now. A commonly cited research for educator effectiveness in undergraduate education space is by Chickering and Gamson (1987) who suggest the principles for good practice. Oliver (1999) explores strategies for efficient online teaching and learning and accentuates the use of online technologies. Teaching effectiveness according to Gorsky and Blau (2009) is about how an instructor can best oversee, guide, facilitate, and support students towards achievement.

Over the last decade, research is directed more towards online teaching effectiveness (Bangert, 2006a, b). In an exploratory study on issues affecting the quality of teaching effectiveness in online classes, Bangert (2006a, b) used the constructs: student and faculty interaction, time spent on the task, active learning, and cooperation among the students to develop an instrument to evaluate online teaching effectiveness through the responses of online students studying in Montana State University. According to Muilenburg and Berge (2005), the barriers to online learning from student side included various technical skills; costs involved; access to the internet; motivation levels of the learners; administrative problems; social relations; academic and theoretical skills; time and provision for studies; and technical problems. In another study, Young (2006) explored student views of online instruction in the different courses in higher education and found that effective online teaching was dependent on several factors including - student needs and how the teachers adapt to them, use of relevant examples, motivation of the students to give their best in the online class, effective course facilitation, effective teacher communication, course delivery, and demonstrating a concern for student learning. Brinkley-Etzkorn (2018) examined a model for teaching and training the new cadre of online instructors and measure the influence of the training on their classroom effectiveness as well as their 
integration of knowledge. It was found out that the instructors demonstrated reasonable advancements in their teaching effectiveness.

\subsubsection{Teaching styles}

Conti (1985) and Sherron and Boettcher (1997) found that that the teaching styles of the instructors facilitate the learning in the classroom by creating an engaging environment for the learners. According to Taylor (2002), both the teachers and the students bring to the online classroom, their own style, abilities, and characteristics. Quitadamo and Brown (2001) through their research, addressed some of the teaching trials for the online instructional experience, and have specifically focused on how teaching styles have been used to not only build the online learning community, but also to develop student problem-solving and critical thinking capabilities, and effectively encourage productive and satisfying learning interactions, and instructors employing facilitative, guidance-based, and collaborative cum interactive teaching styles are able to more successfully create critical thinking prospects for the majority of students (Kember \& Gow, 1994). Another study was conducted by Rodríguez and Fahara (2010) that proposed four styles of online teaching including designer-oriented style, corrector-oriented style, mediator-oriented teaching, and facilitator-oriented style of teaching. In another study, Arsham (2002) in his study considered the impact of the internet and the online courses on the learning and teaching and the various teaching styles. Barrett et al (2007) in their study on the teaching style of online instructors discussed the learner-oriented and teacher-oriented styles of teaching and the potential of online teaching to transition to learner centred teaching style. Barrett (2004) conducted a study to determine whether any differences existed between the different teaching styles of the male and female community college instructors who were teaching online, and results indicated that a learner-centred teaching style as the appropriate method for teaching online.

\subsubsection{Teaching pedagogy}

As far as the teaching pedagogy in online classes is concerned, one major study was conducted by Meyers (2008) which highlighted the use of transformative pedagogical tools while teaching online, in which students were encouraged to reflect on their experiences, values, beliefs, biases, whereby encouraging student engagement, responsiveness, class participation and also by giving practical problems, the facilitators helped students to propose action-oriented and feasible solutions that could be implemented. Another study by Ascough (2002) was conducted where he focuses on putting pedagogy before technology to ensure quality education no matter what the content or mode of delivery. Vrasidas (2004) discussed the pedagogical issues with online teaching and highlights the need to assist the e-learning systems designers to produce technologies which can have substantial impact on the online educational experiences of the students. As per his research, the pedagogy was dependent on the various roles assumed and tasks to be done by the online teachers. Picciano (2006) indicated that pedagogy in online classes is majorly about the level of interaction 
with the students by the teachers. There was also a role of reflective teaching in online teaching. Knowlton (2017) in his study promoted the student-centred pedagogy where the focus on all teaching is on the needs of the student. In a study on the virtual classroom pedagogy, Bower (2006) attempted to create an online collaborative environment and make use of powerful range of pedagogical tools to enhance online teaching.

Also, there exist obscure un-alignments between what is commonly known as online teaching and the crisis remote teaching that has emerged due to the existing conditions (Hodges et al., 2020), including a prevalent organizational infrastructure, which serves the aim of online teaching and learning. This emergency (due to crisis) remote online teaching has been called for due to the Covid-19 pandemic, and has witnessed swift improvisation, without much infrastructural assistance by the institutions. Due to this paucity of infrastructural requirements, the emergent cadre of online teachers who are not literally experts in online teaching, have shifted focus on the accessible technological tools, considered suitable to support the switch (Hodges et al., 2020). Phutela and Dwivedi (2020) conducted a study on the perspective of the Indian students on e-learning adoption in which the drivers and the inhibitors of e-learning adoption have been extensively discussed with respect to the teaching style, effectiveness, and pedagogy. In another study Santally, et al (2020) focus on constant progress in the online teaching and learning practices by enabling e-learning capability in Mauritius through the use of technology. A model for assessing the impact of environmental psychology, learning style, e-learning and school design on the behaviour of elementary school students was proposed and developed by Zhao et al. (2020). Wongwuttiwat et al (2020) in a study on blended e-learning explored the learning achievements amongst university students with regards to traditional face-to-face learning and blended e-learning.

Based on the above literature review, the major constructs of the study identified for the current study include teaching effectiveness, teaching style and pedagogy and Table 1 summarizes the names of the contributing authors.

Table 1 Constructs of the study

\begin{tabular}{ll}
\hline Construct & Authors, Year \\
\hline Teaching Effectiveness & Chickering and Gamson (1987); Oliver (1999); Muilenburg and Berge (2005); \\
& Bangert (2006a, b); Bangert (2008); Gorsky and Blau (2009); Young and \\
& Muller (2010); Brinkley-Etzkorn (2018) \\
Teaching Style & Conti (1985); Kember and Gow (1994); Sherron and Boettcher (1997); Quita- \\
& damo and Brown (2001); Taylor (2002); Barrett (2004); Barrett et al (2007); \\
& Arsham (2002) \\
Pedagogy & Knowlton (2000); Ascough (2002); Vrasidas (2004); Picciano (2006); Bower \\
& (2006); Meyers (2008) \\
\hline
\end{tabular}




\subsection{Compiled by authors}

This compelling need for digitalization of teaching, learning and educational practices during the Covid-19 pandemic is now an evolving topic in research (Jandrić, 2020). Rapanta et al (2020) conducted a study on the university teaching during and post Covid-19 crisis by transferring the focus on the educator's online presence as well as learning activities in the classroom. Sun and Chen (2016) conducted a study on the effectiveness of online education, in which the authors state that it is dependent on well-designed course content and well-prepared instructors, along with a motivated interaction between the instructors and their learners; and rapid technological advancement.

Based on the review of above theory, several unanswered questions have surfaced.

\section{RQ1: Are the online classes as effective amongst the school and college stu-} dents as the traditional classes?

Traditional classroom deals with teachings through a physical interaction between teachers and students. With the Covid-19 situations, the dynamics of teaching and learning have changed. And the question which needs to be answered is if these online classes have been effective amongst the school and college students in comparison to traditional classes or not. There is a need to study the teaching effectiveness, teacher's skills and responsiveness during online classes contributing to the student perception of effectiveness of the online classes.

\section{RQ2: Is there any effect of teaching pedagogy on student perception of online classes?}

Traditional classroom teaching and online teaching give a different experience to learning on part of the students. What are the differences in both the pedagogies? Which pedagogy is considered more effective by the students?

Against this background, the primary research objective of the present study is to explore the students' perception towards online education.

\section{Methods}

This study is exploratory in nature and is based on a descriptive research design, using primary data. A survey was administered using a structured questionnaire as the research tool. Convenience sampling method has been used to collect the responses. A structured questionnaire was shared on social media (LinkedIn, Facebook), email ids and WhatsApp in Delhi NCR, India. In total, 375 responses were received in the stipulated time out of which only 356 were complete in all aspects and responded positively to online classes being conducted at their respective institutions. Therefore, the sample size of 356 was used for the study. 
All student respondents answered the same questions from the online teaching pedagogy and effectiveness questionnaire. The questionnaire was divided into two parts, of which part one was used to collect the demographic details of the respondents and part two on the other hand, consisted of the opinions about the online teaching pedagogy and effectiveness.

The statistical package SPSS 25.0 (IBM) was used. The parameter of $\mathrm{p}<0.05$ to deduct the level of significance. Chi-Square analysis was used to establish a sense of association, t-test was used to establish differences in mean effectiveness based on type of educational institutions and student's gender, Analysis of Variance (ANOVA) used to establish differences in mean effectiveness student's age and regression model to quantify the predictors of this new pedagogy.

\subsection{Research objectives}

- To study the effect of pedagogy, teaching style and effectiveness on student perception in online classes from teachers who had no past experience of online teaching.

- To find out the effect for institution type on teacher's skill, responsiveness, and teaching effectiveness.

- To explore the gender-wise effect of teacher feedback score, teacher's skill, responsiveness, and teaching effectiveness.

- To study the difference in teacher's skill, responsiveness, and teaching effectiveness between age groups.

\subsection{Hypothesis}

Based on the research question, four different hypotheses were tested and were based on the research questions.

$\mathrm{H}_{0(\mathrm{a})}$ : There is no significant effect of pedagogy, teaching style, effectiveness \& associated indicators on student perception about online classes.

$\mathrm{H}_{0 \text { (b) }}$ : There is no significant effect for institutional type on teacher's skill, responsiveness, and teaching effectiveness.

$\mathrm{H}_{0(\mathrm{c})}$ : There is no significant effect for gender on teacher feedback score, teacher's skill, responsiveness, and teaching effectiveness.

$\mathrm{H}_{0 \text { (d) }}$ : There is no significant difference in teacher's skill, responsiveness, and teaching effectiveness between age groups.

\section{Findings and discussion}

The demographic analysis of the study population of the survey respondents indicate that of the 356 respondents, $29.49 \%$ respondents were 18 years of age or less; $39.89 \%$ respondents were $19-22$ years whereas rest of the $30.62 \%$ respondents 
Table 2 Cross tabulated chi squares for pedagogy variables with student perception about online classes able to achieve course learning outcomes

\begin{tabular}{lccc}
\hline Pedagogy variables & Chi-Square & df & Asymp. Sig \\
\hline Teacher's effectiveness & 45.28 & 4 & 0.004 \\
Teacher holding attention in class & 244.69 & 4 & 0.010 \\
Teacher's being trained to conduct online classes & 65.87 & 4 & 0.001 \\
Teachers are comfortable in conducting online classes & 62.72 & 4 & 0.012 \\
Teachers are able to focus on students requiring extra help & 51.79 & 4 & 0.001 \\
Teachers were able to manage the online class better than the & 380.35 & 4 & 0.010 \\
$\quad$ traditional class & & & \\
Teacher was an effective lecturer/demonstrator & 301.23 & 4 & 0.001 \\
Teacher stimulated student interest? & 128.86 & 4 & 0.002 \\
Teacher effectively used time during class periods? & 217.79 & 4 & 0.001 \\
Teacher was available and helpful? & 317.79 & 4 & 0.001 \\
Grading was prompt and had useful feedback & 159.04 & 4 & 0.001 \\
\hline
\end{tabular}

were more than 23 years in age. Majority of the respondents $(70.51 \%)$ are above 18 years of age and are either school or University students, during the time of the study.

In answering the research questions and to test the hypothesis, regarding the student perception towards online classes by first time online teachers, the following calculations were carried out. The results testing the hypothesis are explained below with the corresponding tables and explanations.

Table 2 shows the chi square analysis for the pedagogy variables with student perception about online classes able to achieve course learning outcomes. All associations came out to be significant, hence pedagogy, teaching style, the effectiveness along with all other associated indicators are significantly affect student perception about online classes and if they help in achieving course learning outcomes $(\mathrm{p}<0.05)$. Thus, the null hypothesis $\mathrm{H}_{0(\mathrm{a})}$ is rejected.

Levene's Test $(F)$ for Equality of Variances has been used here with assumption that the variances for the two groups viz. school and college are equal as shown in Table 3. The gap between the two defined categories is statistically significant for all selected variables $(\mathrm{p}>0.05)$. It connotes that a significant difference exists between the school and college group. Thus, equal variance not assumed row is selected for conducting the Independent sample T-Test. For variable Teaching effectiveness, the Independent sample test results at 113.044 degree of freedom $t_{113.044}=-1.296$, $\mathrm{p}=0.198>0.05$. Therefore, the difference between school and college on the Teaching effectiveness construct is statistically non-significant at 5\% level of significance. For variable Teacher feedback score, Independent sample test results at 151.569 degree of freedom $t_{151.569}=2.498, \mathrm{p}<0.05$. Therefore, the difference between School and college on the Teacher feedback score is statistically significant at $5 \%$ level of significance. Thus, the school students perceive it more than the College $\left(\mu_{\text {school }}=1.9702>\mu_{\text {college }}=1.8110\right)$. For variable Teacher's skill and responsiveness score Independent sample test results at 115.802 degree of freedom $t_{115.802}=-0.820$, 


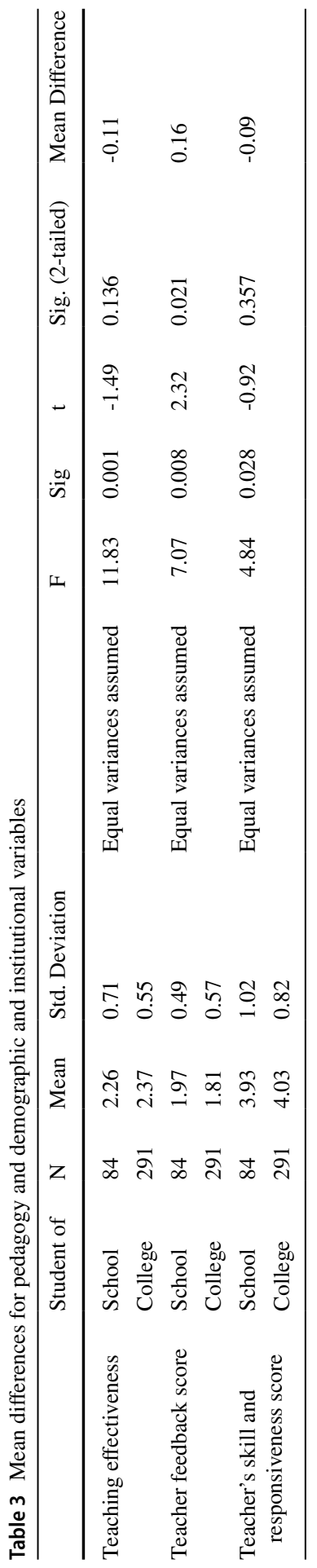




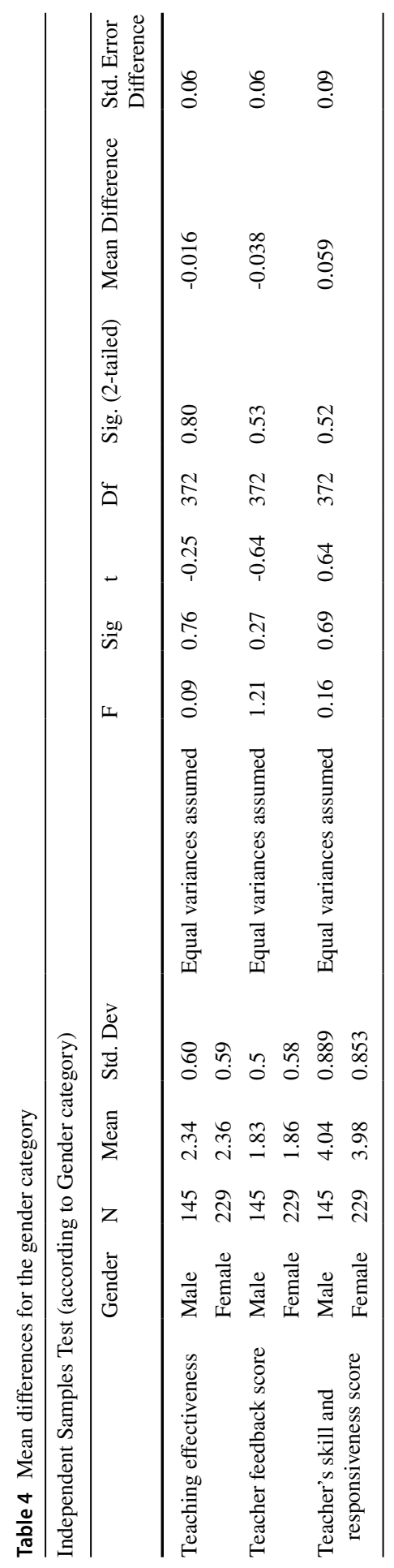


$\mathrm{p}<0.05$. Therefore, the difference between school and college on the Teacher's skill and responsiveness score is statistically non-significant at 5\% level of significance. Thus, the null hypothesis $\mathrm{H}_{0(\mathrm{~b})}$ is accepted.

According to gender for variable Teaching effectiveness Independent sample test results at 372 degree of freedom $t_{372}=-0.251, p>0.05$ (Refer Table 4). Therefore, the gender wise difference between on the Teaching effectiveness construct is statistically non-significant at 5\% level of significance. For variable Teacher feedback score Independent sample test results at 372 degree of freedom $t_{372}=-0.637$, $\mathrm{p}>0.05$. Therefore, the gender wise difference between on the Teacher feedback score is statistically non-significant at $5 \%$ level of significance. For variable Teacher's skill and responsiveness score Independent sample test results at 372 degree of freedom $\mathrm{t}_{372}=0.639, \mathrm{p}>0.05$. Therefore, the gender wise difference between on the Teacher's skill and responsiveness score is statistically non-significant at $5 \%$ level of significance. Thus, the null hypothesis $\mathrm{H}_{0(\mathrm{c})}$ is accepted.

Table 5 Results of the ANOVA indicated that there were not significant differences in teacher's skill and responsiveness score and teaching effectiveness between age groups. ANOVA also indicated that there were significant differences in teacher feedback score $(\mathrm{F}=7.718, \mathrm{p}=0.001)$. Thus, the null hypothesis $\mathrm{H}_{0(\mathrm{~d})}$ is accepted

Table 6 shows the results from the pre-online level of skills/knowledge at start of online classes $(\mathrm{M}=2.97, \mathrm{SD}=1.11)$ and post-online level of skills/knowledge at start of online classes $(M=3.03, S D=1.17)$ with the values of $t_{(355)}=-0.965$, $\mathrm{p}=0.335$ the results indicated that the online classes did not significantly change the skill/knowledge.

Table 7 shows results of the multiple linear regression indicated that there was a collective effect of the Teaching effectiveness, Teacher feedback score, Teacher's skill and responsiveness score, Gender, Age and College vs school student on contribution to overall learning $\left(\mathrm{R}^{2}=0.206\right)$. the variance in dependent variables was explained to a degree of 20.6 percent by independent selected and demographical variables in the model, also the ANOVA analysis further shows the model fit as

Table 5 Mean differences for pedagogy and age groups

\begin{tabular}{lllllll}
\hline Categories & Age group & N & Mean & SD & ANOVA & Sig. (2-tailed) \\
\hline Teaching effectiveness & $<18$ years & 105 & 1.33 & 0.24 & 0.85 & 0.430 \\
& 19-22 years & 142 & 1.33 & 0.25 & & \\
& $>23$ years & 109 & 1.29 & 0.26 & & \\
& Total & 356 & 1.31 & 0.25 & & \\
Teacher feedback score & $<18$ years & 105 & 2 & 0.51 & 7.72 & 0.001 \\
& 19-22 years & 142 & 1.78 & 0.53 & & \\
& $>23$ years & 109 & 1.73 & 0.57 & & \\
Teacher's skill and respon- & Total & 356 & 1.83 & 0.55 & & \\
siveness score & $19-22$ years & 105 & 3.84 & 0.78 & 0.06 & \\
& $>23$ years & 109 & 3.86 & 0.69 & & \\
& Total & 356 & 3.84 & 0.75 & & \\
\hline
\end{tabular}




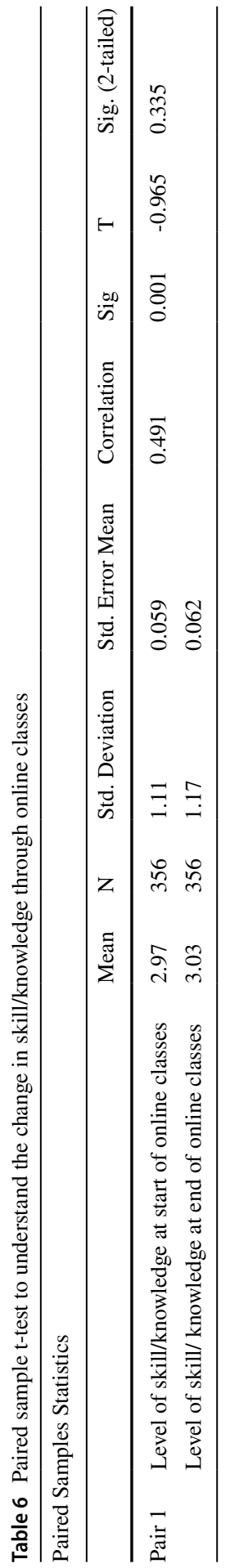




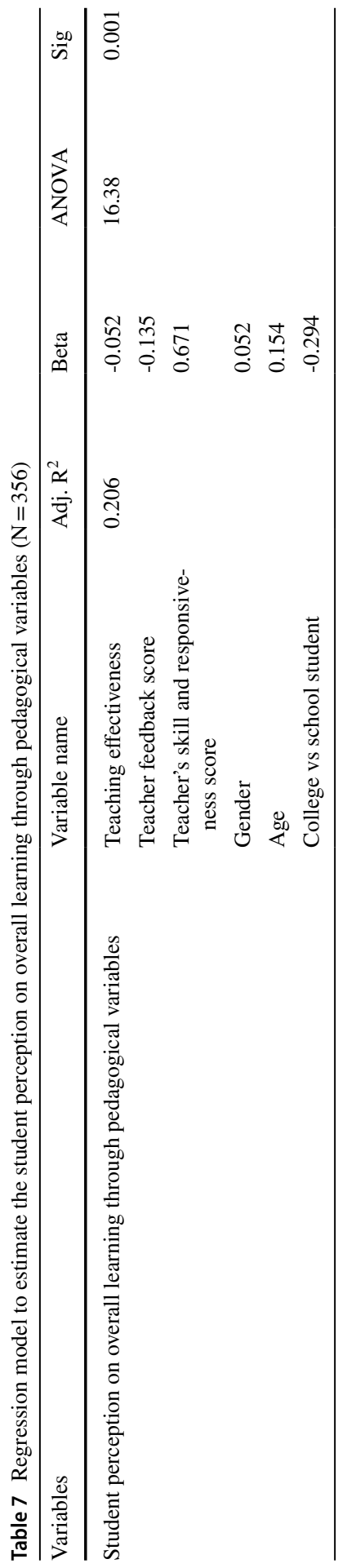



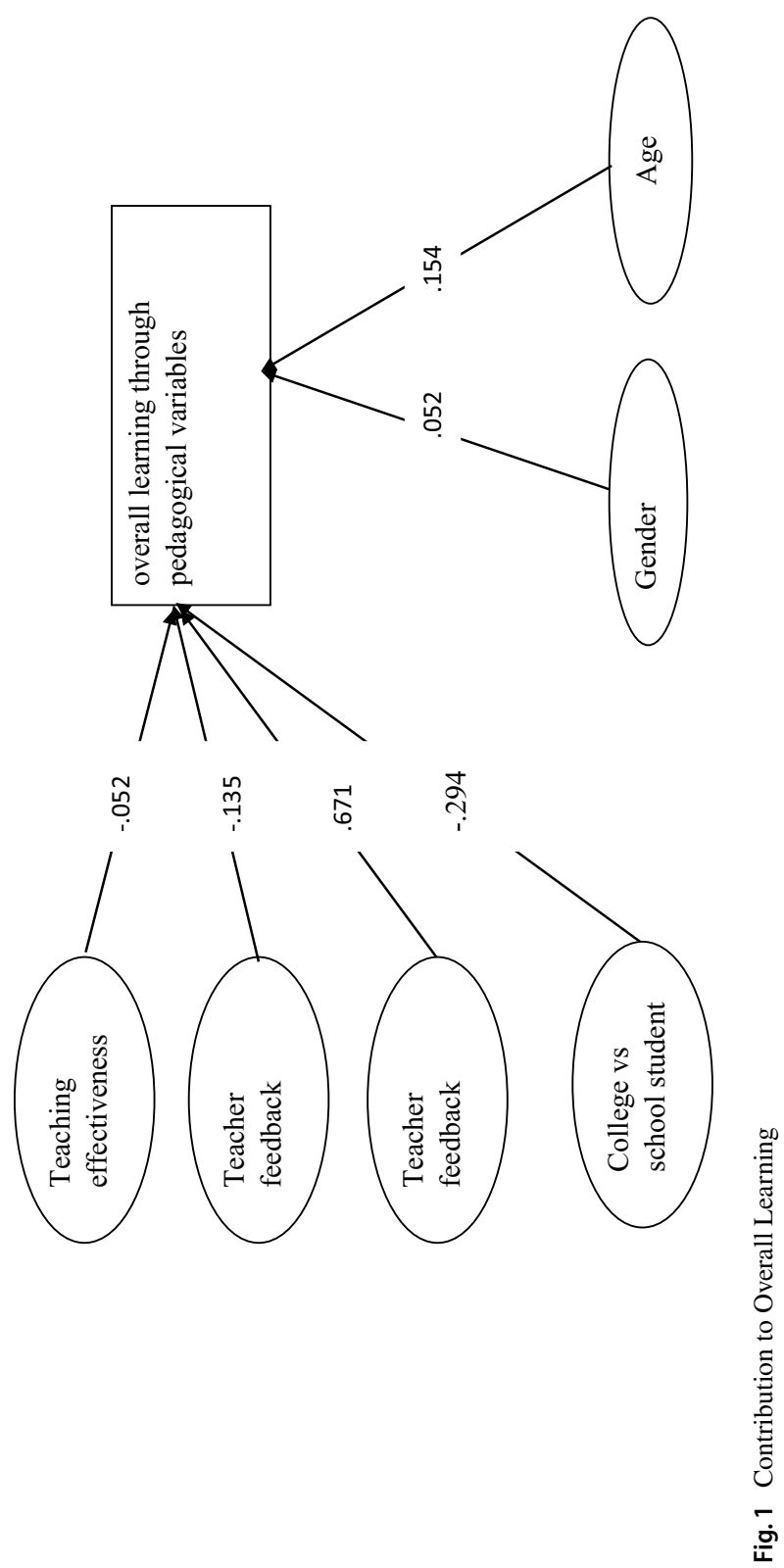
$\mathrm{F}=16.38$ with $\mathrm{p}<0.001$. Thus, we can establish the relationship of Teaching effectiveness, Teacher feedback score, Teacher's skill and responsiveness score, Gender, Age and College vs school student on contribution to overall learning. Figure 1 indicates the contribution to the overall learning.

\section{Conclusions, limitations, recommendations and future scope of research}

A collection of methodical and logical conclusions drawn from the above research findings are discussed here.

\subsection{Conclusions}

The present study was carried out to study the perception of students towards online classes. The statistical analysis has reinforced the conclusions arrived at. Based on the statistical analysis we come to the following conclusions for the hypothesis framed for the research given below in Table 8 .

From the above results, we come to the conclusion that as there is a significant effect of pedagogy, teaching style, effectiveness \& associated indicators on student perception about online classes, therefore it becomes imperative for educational institutes to create a cadre of well-trained teachers equipped with the suitable pedagogical tools to create an effective online classroom. Furthermore, as there is no significant effect for institutional type, gender and age groups on teacher's skill, responsiveness, and teaching effectiveness, it implies that students of these demographic groups had a similar learning experience in the virtual learning environment.

The role of the teacher in this online format of teaching takes on a hint of a protagonist in the new classroom environs, in order to give way to a pedagogical process that not only equals the results of face-to-face teaching but also exceeds it. There is no doubt that the dynamic online classroom develops its own life, based on the teacher's ability to monitor, guide and deliver the course, making adjustments based on learners' needs, goals and interests, as and when they arise.

Table 8 Summary showing Acceptance and Rejection of the Hypothesis

\begin{tabular}{lll}
\hline $\mathrm{H}_{0(\mathrm{a})}$ & $\begin{array}{c}\text { There is no significant effect of pedagogy, teaching style, effectiveness \& } \\
\text { associated indicators on student perception about online classes }\end{array}$ & REJECTED \\
$\mathrm{H}_{0(\mathrm{~b})}$ & $\begin{array}{l}\text { There is no significant effect for institutional type on teacher's skill, respon- } \\
\text { siveness, and teaching effectiveness }\end{array}$ & ACCEPTED \\
$\mathrm{H}_{0(\mathrm{c})}$ & $\begin{array}{l}\text { There is no significant effect for gender on teacher feedback score, teacher's } \\
\text { skill, responsiveness, and teaching effectiveness }\end{array}$ & ACCEPTED \\
$\mathrm{H}_{0(\mathrm{~d})}$ & $\begin{array}{l}\text { There is no significant difference in teacher's skill, responsiveness, and } \\
\text { teaching effectiveness between age groups }\end{array}$ & ACCEPTED \\
\hline
\end{tabular}


Internet is on the path of a major technological progression, reshaping not only the educational institutions worldwide, but our society as a whole. In the light of this, schools, colleges, and universities have to capitalise on the web for teaching and make extensive use of online delivery methods to make online teaching effective.

\subsection{Recommendations}

Based on the above study, the following recommendations are being made:

- Formal training can be imparted to the teachers not only to enhance their teaching effectiveness, but also on improving their style of teaching.

- Innovative pedagogical tools for the easy understanding and use of the teachers can be made available by the institutions to make online classes effective.

- The nature of the teacher's job has drastically changed during the pandemic due to which the institutions should periodically assess their training needs so as to monitor any gaps in their teaching.

- Special perks or incentives may be given to those teachers whose classes are found interesting and engaging by the students. This will not only boost the morale of these first-time online teachers, but also these identified teachers may be a role model for the others to follow.

Apart from the above recommendations, the following suggestions are listed out on the basis of information collected from the questionnaire under the column in 'any suggestions.'

- Applications used for online classes or training should make their usage more user friendly as most people using them face issues. It would be helpful if they also provided telephonic solutions as and when problems arrived.

- From student's perspective the teachers should provide more practical assignments to keep them engaged.

- Students feel shy or uncomfortable while asking queries in online classes so teachers should develop a way of encouraging their participation.

- Courses like MBA should have experiential pedagogy with more of case discussion, videos, activities, and situation-based class discussions in the online class. Practical courses like engineering, medicine etc. need to develop a mechanism to impart the practical and lab-based teaching.

- The screen time of the online classes should be monitored by the institutions, as the longer class hours are leading to a negative impact on the eyesight.

- Life skills and value-based education should be enforced with mandatory sessions included in the weekly timetable. This is all the more relevant during this pandemic, as students are confined to the walls of their home and are missing out these valuable lessons.

- The online classes should have a component of peer learning which is being missed by the students as they study from the environs of their homes. 
- Teachers need to match the learning speed of all the students, and concentrate on all the students, rather than only a few. The focus should not be on completing the syllabus.

- Self-learning culture must be promoted within students, who are used to the traditional handholding by their teachers.

- For each subject, the teachers should upload the reading material but ensure that their teaching gets supplemented with these resources, rather than being the only source of teaching.

- Students shared that the major barriers to online learning were constant distraction at home, network and connectivity issues, and restricted data packs.

\subsection{Limitations}

The study is limited to the students of Delhi NCR region in India. The study does not cover international university students where the experience of students for online education may be more than their Indian counterparts. Moreover, online education differs with respect to school, course, Institute and University. New developments are happening in the field of education and regular transformation is taking place in online platform, but their adoption and implementation may not be consistent across the country.

\subsection{Scope for future research}

The present study measures the student perception towards the online classes with respect to only three constructs viz. teaching effectiveness, teaching styles and pedagogy. Therefore, there is a scope for further research concentrating on other constructs like technology. Also, this study is taking into consideration the perspectives of both the school students and college students. Independently these groups can also be taken with respect to senior, middle and junior level school students, and college students enrolled in technical and non-technical programs. A comparative study may also be done for both these groups.

Acknowledgements The authors are extremely grateful to Dr. Prerna Bhasin of Inspire Analytics Ltd UK for her valuable insights during the initial discussion of our research. We are also grateful to the respondents of our study for taking out time during this pandemic period.

\section{Declarations}

Conflict of interest None. 


\section{References}

Agrawal, V., Agrawal, A., \& Agarwal, S. (2016). Assessment of factors for e-learning: An empirical investigation. Industrial and Commercial Training, 48(8), 409-415. https://doi.org/10.1108/ ICT-03-2016-0015.

Arsham, H. (2002). Impact of the Internet on Learning and Teaching. USDLA Journal, 16(3). Retrieved from https://www.learntechlib.org/p/93561/.

Ascough, R. S. (2002). Designing for Online Distance Education: Putting Pedagogy Before Technology. Teaching Theology and Religion, 5(1), 17-29. https://doi.org/10.1111/1467-9647.00114.

Bangert, A. W. (2006a). The Development of an Instrument for Assessing Online Teaching Effectiveness. Journal of Educational Computing Research, 35(3), 227-244. https://doi.org/10.2190/ b3xp-5k61-7q07-u443.

Bangert, A. W. (2006b). Identifying factors underlying the quality of online teaching effectiveness: An exploratory study. Journal of Computing in Higher Education, 17, 79-99. https://doi.org/10.1007/ BF03032699.

Bangert, A. W. (2008). The Development and Validation of the Student Evaluation of Online Teaching Effectiveness. Computers in the Schools, 25(1-2), 25-47. https://doi.org/10.1080/073805608021577 17.

Barrett, K. R. (2004). A Comparison of Online Teaching Styles in Florida Community Colleges. Retrieved on June 5, 2020 from http://purl.flvc.org/fsu/fd/FSU_migr_etd-7034.

Barrett, K. R., Bower, B. L., \& Donovan, N. C. (2007). Teaching Styles of Community College Instructors. American Journal of Distance Education, 21(1), 37-49. https://doi.org/10.1080/0892364070 1298738.

Bower, M. (2006). Virtual classroom pedagogy. Proceedings of the 37th SIGCSE Technical Symposium on Computer Science Education - SIGCSE '06. https://doi.org/10.1145/1121341.1121390.

Bower, M. (2017). Designing for Learning Using Virtual Worlds. Design of Technology-Enhanced Learning, 305-364. https://doi.org/10.1108/978-1-78714-182-720171012.

Brinkley-Etzkorn, K. E. (2018). Learning to teach online: Measuring the influence of faculty development training on teaching effectiveness through a TPACK lens. The Internet and Higher Education, 38, 28-35. https://doi.org/10.1016/j.iheduc.2018.04.004.

Chickering, A. W., \& Gamson, Z. F. (1987). Seven Principles of good practice in undergraduate education. AAHE Bulletin, 39(7), 3-7.

Chopra, G., Madan, P., Jaisingh, P., \& Bhaskar, P. (2019). Effectiveness of e-learning portal from students' perspective: A structural equation model (SEM) approach. Interactive Technology and Smart Education, 16(2), 94-116. https://doi.org/10.1108/ITSE-05-2018-0027.

Conti, G. J. (1985). Assessing teaching style in adult education: How and why. Lifelong Learning, 8(8), 7-11, 28 .

Dillon, C. L., \& Gunawardena, C. N. (1995). A framework for the evaluation of telecommunicationsbased distance education. In D. Stewart (Ed.), Selected Papers from the 17th Congress of the International Council for Distance Education (Vol. 2, pp. 348-351). Open University.

Discenza, R., Howard, C., \& Schenk, K. (2002). The design \& management of effective distance learning programs. Idea Group Gil OrtegaPublishing. https://doi.org/10.4018/978-1-930708-20-4.

Dwivedi, A., Dwivedi, P., Bobek, S., \& Sternad Zabukovšek, S. (2019). Factors affecting students' engagement with online content in blended learning. Kybernetes, 48(7), 1500-1515. https://doi.org/ 10.1108/K-10-2018-0559.

Efiloğlu, K. Ö., \& Tingöy, Ö. (2017). The acceptance and use of a virtual learning environment in higher education: an empirical study in Turkey, and the UK. International Journal of Educational Technology in Higher Education, 14(1), 26. https://doi.org/10.1186/s41239-017-0064-Z.

Federman, J. E. (2019). Interruptions in online training and their effects on learning. European Journal of Training and Development, 43(5/6), 490-504. https://doi.org/10.1108/EJTD-10-2018-0100.

Garrison, D., \& Kanuka, H. (2004). Blended learning: Uncovering its transformative potential in higher education. The Internet and Higher Education, 7(2), 95-105. https://doi.org/10.1016/j.iheduc.2004. 02.001 .

Garrison, D. R., Cleveland-Innes, M., \& Fung, T. (2004). Student role adjustment in online communities of inquiry: Model and instrument validation. Journal of Asynchronous Learning Networks, 8(2), $61-74$. 
Gorsky, P., \& Blau, I. (2009). Online Teaching Effectiveness: A Tale of Two Instructors. The International Review of Research in Open and Distributed Learning, 10(3). https://doi.org/10.19173/irrodl. v10i3.712.

Gunesekera, A. I., Bao, Y., \& Kibelloh, M. (2019). The role of usability on e-learning user interactions and satisfaction: A literature review. Journal of Systems and Information Technology, 21(3), 368394. https://doi.org/10.1108/JSIT-02-2019-0024.

Harasim, L. (2000). Shift happens: Online education as a new paradigm in learning. The Internet and Higher Education, 3(1-2), 41-61. https://doi.org/10.1016/s1096-7516(00)00032-4.

Hartley, K., \& Bendixen, L. D. (2001). Educational research in the Internet age: Examining the role of individual characteristics. Educational Researcher, 30(9), 22-26. https://doi.org/10.3102/00131 89X030009022.

Hill, J. R. (2002). Overcoming obstacles and creating connections: community building in web-based learning environments. Journal of Computing in Higher Education, 14(1), 67-86. Retrieved August 2, 2020 from https://www.learntechlib.org/p/93177/.

Hodges, C., Moore, S., Lockee, B., Trust, T., \& Bond, A. (2020). The difference between emergency remote teaching and online learning. Educause Review, 27 March. Accessed 15 Jun 2020 from https://er.educause.edu/articles/2020/3/thedifference-between-emergency-remote-teaching-andonline-learning.

Jandrić, P. (2020). Postdigital research in the time of Covid-19. Postdigital Science and Education, 2(2), 233-238. https://doi.org/10.1007/s42438-020-00113-8.

Kember, D., \& Gow, L. (1994). Orientations to Teaching and Their Effect on the Quality of Student Learning. Journal of Higher Education, 65(1), 58-74. https://doi.org/10.1080/00221546.1994. 11778474.

Knowlton, D. S. (2000). A Theoretical Framework for the Online Classroom: A Defense and Delineation of a Student-Centered Pedagogy. New Directions for Teaching and Learning, 2000(84), 5-14. https://doi.org/10.1002/t1.841.

Knowlton, B. J. (2017). Learning and memory: A comprehensive reference. Procedural Learning in Humans, 295-312. https://doi.org/10.1016/B978-0-12-809324-5.21085-7.

Leidner, D. E., \& Jarvenpaa, S. L. (1993). The information age confronts education: Case studies on electronic classroom, Information Systems Research. No., 4, 24-54. https://doi.org/10.1287/isre.4.1.24.

Loh, C., Wong, D. H., Quazi, A., \& Kingshott, R. P. (2016). Re-examining students' perception of e-learning: An Australian perspective. International Journal of Educational Management, 30(1), 129-139. https://doi.org/10.1108/IJEM-08-2014-0114.

Meyers, S. A. (2008). Using Transformative Pedagogy When Teaching Online. College Teaching, 56(4), 219-224. https://doi.org/10.3200/ctch.56.4.219-224.

Muilenburg, L. Y., \& Berge, Z. L. (2005). Student barriers to online learning: A factor analytic study. Distance Education, 26(1), 29-48. https://doi.org/10.1080/01587910500081269.

Oliver, R. (1999). Exploring strategies for online teaching and learning. Distance Education, 20(2), 240254. https://doi.org/10.1080/0158791990200205.

Parker, M., \& Martin, F. (2010). Using Virtual Classrooms: Student perceptions of features and characteristics in an online and a blended course. MERLOT Journal of Online Learning and Teaching, $6(1), 135$.

Phutela, N. \& Dwivedi, S. (2020), A qualitative study of students' perspective on e-learning adoption in India. Journal of Applied Research in Higher Education, Vol. ahead-of-print No. ahead-of-print.

Picciano, A. (2006). Online Learning: Implications for Higher Education Pedagogy and Policy. Journal of Thought, 41(1), 75-94. Retrieved August 29, 2020, from http://www.jstor.org/stable/42589857.

Quitadamo, I. J. \& Brown, A. (2001). Effective Teaching Styles and Instructional Design for Online Learning Environments. Accessed Jun 2, 2020 from http://confreg.uoregon.edu/necc2001/program/.

Rapanta, C., Botturi, L., Goodyear, P., Guàrdia, L., \& Koole, M. (2020). Online University Teaching During and After the Covid-19 Crisis: Refocusing Teacher Presence and Learning Activity. Postdigital Science and Education. https://doi.org/10.1007/s42438-020-00155-y.

Rodríguez, A. L., \& Fahara, M. F. (2010). Online Teaching Styles: A Study in Distance Education. International Journal of University Teaching and Faculty, 1(2), 1-14.

Roper, A. R. (2007). How students develop online learning skills. Educause Quarterly, 30(1), 62-64.

Samsudeen, S. N., \& Mohamed, R. (2019). University students' intention to use e-learning systems. Interactive Technology and Smart Education. https://doi.org/10.1108/itse-11-2018-0092. 
Santally, M. I., Rajabalee, Y. B., Sungkur, R. K., Maudarbocus, M. I. \& Greller, W. (2020). Enabling continuous improvement in online teaching and learning through e-learning capability and maturity assessment. Business Process Management Journal, Vol. ahead-of-print No. ahead-of-print.

Sarker, M. F. H., Mahmud, R. A., Islam, M. S., \& Islam, M. K. (2019). Use of e-learning at higher educational institutions in Bangladesh. Journal of Applied Research in Higher Education. https://doi.org/ 10.1108/jarhe-06-2018-0099.

Schullo, S., Hilbelink, A., Venable, M. \& Barron, A. (2007) Selecting a Virtual Classroom System: Elluminate Live vs. Macromedia Breeze (Adobe Acrobat Connect Professional). MERLOT Journal of Online Learning and Teaching, 3(4). http://jolt.merlot.org/vol3no4/hilbelink.htm.

Sherron, G. T. \& Boettcher, J. V. (1997). Distance learning: The shift to interactivity. Professional Paper Series, No. 17. Bolder, CO: CAUSE, the Association for Managing and Using Information Resources in Higher Education.

Storck, J., \& Sproull, L. (1995). Through a glass darkly \pm what people learn in videoconferences? Human Communication Research, 22, 197-219. https://doi.org/10.1111/j.1468-2958.1995.tb00366.x.

Subramaniam, N. S., \& Kandasamy, M. (2011). The virtual classroom: A catalyst for institutional transformation. Australasian Journal of Educational Technology, 27(Special issue, 8), 1388-1412. https://doi.org/10.14742/ajet.900.

Sun, A. \& Chen, X. (2016). Online education and its effective practice: A research review. Journal of Information Technology Education: Research, 15, 157-190. Retrieved from http://www.informings cience.org/Publications/3502.

Taylor, R. W. (2002). Pros and cons of online learning - a faculty perspective. Journal of European Industrial Training, 26(1), 24-37. https://doi.org/10.1108/03090590210415876.

Ugnich, E., Meskhi, B., Ponomareva, S., Roberts, Brian, \& Popkova, Elena. (2019). E-learning in higher inclusive education: needs, opportunities and limitations. International Journal of Educational Management. https://doi.org/10.1108/IJEM-09-2018-0282.

Young, M, Muller, J. (2010). Three educational scenarios for the future: Lessons from the sociology of knowledge 45(1), 11-27. https://doi.org/10.1111/j.1465-3435.2009.01413.x.

Visvizi, A., Lytras, M. D. \& Daniela, L. (2019). The future of innovation and technology in education: policies and practices for teaching and learning excellence, United Kingdom. Emerald Publishing. https://doi.org/10.1108/978-1-78756-555-520181014.

Vrasidas, C. (2004). Issues of pedagogy and design in e-learning systems. Proceedings of the 2004 ACM Symposium on Applied Computing - SAC '04. https://doi.org/10.1145/967900.968086.

Webster, J., \& Hackley, P. (1997). Teaching effectiveness in technology-mediated distance learning. Academy of Management Journal, 40(6), 1282-1309. https://doi.org/10.5465/257034.

Wetzel, C. D., Radtke, P. H., \& Stern, H. W. (1994). Instructional Effectiveness of Video Media. Laurence Erlbaum.

Wongwuttiwat, J., Buraphadeja, V. \& Tantontrakul, T. (2020). A case study of blended e-learning in Thailand. Interactive Technology and Smart Education, Vol. ahead-of-print No. ahead-of-print.

Woollard, J. (2011). Initial Teacher Training in a Virtual World. Cutting-Edge Technologies in Higher Education, 29-46. https://doi.org/10.1108/s2044-9968(2011)0000004006.

Ya Ni, A. (2013). Comparing the Effectiveness of Classroom and Online Learning: Teaching Research Methods. Journal of Public Affairs Education, 19(2), 199-215. https://doi.org/10.1080/15236803. 2013.12001730.

Young, S. (2006). Student Views of Effective Online Teaching in Higher Education. American Journal of Distance Education, 20(2), 65-77. https://doi.org/10.1207/s15389286ajde2002_2.

Zhao, X., Wang, J., Wang, M., Li, X., Gao, X. and Huang, C. (2020). "A new model for assessing the impact of environmental psychology, e-learning, learning style and school design on the behavior of elementary students". Kybernetes, Vol. ahead-of-print No. ahead-of-print.

Publisher's Note Springer Nature remains neutral with regard to jurisdictional claims in published maps and institutional affiliations. 